Külgazdaság, LXIII. évf., 2019. november-december (73-94. o.)

\title{
Konvergencia vagy közepes jövedelmi csapda? - Lengyelország lehetőségei az európai integrációra SZENNAY ÁRON
}

Lengyelország Kelet-Közép-Európa és a Visegrádi államok meghatározó országa. A térség más tranzíciós gazdaságaihoz hasonlóan Lengyelország gazdasági-politikai mozgásterét gazdasági teljesitménye, geopolitikai elhelyezkedése, valamint a külsö eröforrások importjára (például: külföldröl beáramló müködö tőke - FDI, földgáz stb.) való ráutaltsága jelentösen korlátozza. A kutatás célja annak azonositása, hogy Lengyelország miként csatlakozhat az Európai Unió magországainak köréhez. A vizsgálat kiterjed az ország fejlödési irányait befolyásoló föbb tényezőkre, így föként közlekedési helyzetére, az energiabiztonságra, a klímaváltozásra, a kis-és közepes vállalkozásokra és a valutapolitikára. Lengyelország elemzésének aktualitását adja, hogy a szocialista múlt, valamint a rendszerváltás módja a gazdasági felzárkózáshoz hasonló kiinduló terepet nyújtott, eltérést elsösorban az ország földrajzi mérete és népessége jelent - ami ideális terepet nyújt az összehasonlitások elvégzésére, a Magyarország számára is alkalmazható kitörési lehetőségek meghatározására. A szerzö vegyes módszertant alkalmaz, ugyanis a különbözö statisztikai adatok, tervek és sajtótermékek mellett a vonatkozó hazai és a nemzetközi szakirodalmat egyaránt feldolgozza.*

Journal of Economic Literature (JEL) kód: F520, Q480.

* A tanulmány az MTA-BGE Makrogazdasági fenntarthatósági kutatócsoport mint munkahely keretében, a Támogatott Kutatócsoportok Irodájának támogatásával készült. A szerző a kutatócsoport tagja.

https://doi.org/10.47630/KULG.2019.63.11-12.73

A szerzö ezúton is köszönetét fejezi ki Bernek Ágnesnek és az anonim lektornak a kapott konstruktív javaslatokért, észrevételekért. A tanulmány elkészültét az EFOP-3.6.1-16-2016-00012. sz. Intelligens szakosodást szolgáló intézményi fejlesztések - Innovatív megoldásokkal Zala megye $\mathrm{K}+\mathrm{F}+\mathrm{I}$ tevékenysége hatékonyságának növeléséért címü program támogatta

Szennay Áron, egyetemi tanársegéd, BGE Pénzügyi és Számviteli Kar, PhD-hallgató, SZE Regionális és Gazdaságtudományi Doktori Iskola. E-mail: szennay.aron@uni-bge.hu 
Lengyelország területét, lakosságszámát, valamint gazdasági teljesítményét tekintve Kelet-Közép-Európa egyik meghatározó állama. A Litvániával (perszonál) unióra lépett Lengyelország a 14. században Kelet-Európa meghatározó hatalmává vált, a 16-17. században azonban Oroszországgal vívott háborúk nyomán vazallus állam lett. Az ország többszöri felosztását követően csupán az I. világháborút követően nyerte vissza szuverenitását. Ez a függetlenség - a Német Birodalom és a Szovjetunió között - csupán 1939-ig tartott, majd az 1944-es szovjet megszállást követően csak 1990-re vált ismét függetlenné (Lisiakiewicz, 2018).

A történelmi események egyenes következménye Lengyelország eröteljes nyugati orientációja, amelynek megfelelően 1999 óta a NATO, 2004 óta pedig az Európai Unió tagja. Lengyelország GDP-arányos védelmi kiadásait tekintve a hatodik legnagyobb költségvetéssel rendelkező tagállam (NATO, 2019). Ugyanakkor a védelmi büdzsé ezen szintjével sem éri el az elvárt 2 százalékos GDP-arányos szintet. A NATO melletti elkötelezettséget mutatja, hogy bár az országban jelenleg is 4500 amerikai katona állomásozik (Der Spiegel, 2018a), egy állandó amerikai katonai bázis létrehozásáért az ország 2 milliárd dollárt lenne hajlandó fizetni. Emellett az ország az amerikai fegyvergyárak egyik jelentős ügyfele. ${ }^{1}$

Figyelemre méltó emellett az ország gazdaságának az Európai Unió magállamaihoz való felzárkózása is. Az Eurostat adatai alapján a vásárlóerő-paritáson mért egy főre jutó GDP 1995-ben az EU-15 átlagának 37, addig 2018-ban a 66 százalékát tette ki. Szimbolikus lépés, hogy a FTSE Russel1 2018 szeptemberében Lengyelországot - a volt keleti blokk államaiból elsőként - a felzárkózó piacok közül a fejlett piacok közé sorolta át (Raszkowski és Bartniczak, 2019). Ugyanebben az időszakban Magyarország az EU-15 átlagához képest mért 44 százalékról csupán a 65 százalékos szintre tudott felzárkózni (Eurostat, 2019).

Lengyelország gazdasága számára a legnagyobb lehetőséget belső piaca jelenti, ami lehetővé teszi a hazai vállalatok külpiacra lépéséhez szükséges kritikus tömeg elérését - erre jó példa a Solaris busz-, illetve villamosgyár ${ }^{3}(H V G, 2016)$ vagy a

${ }^{1}$ Lengyelország 2016-ban felbontotta az 50 (európai) Airbus katonai helikopter beszerzésére vonatkozó szerződést, hogy amerikai eszközöket vásároljon (Handelsblatt, 2016). 2018-ban készségét fejezte ki egy amerikai hadosztály állomásoztatásának finanszírozására, továbbá 4,75 milliárd dollár értékben rendelt Patriot rakétarendszereket (Lisiakiewicz, 2018). A korszerütlen MIG-29 vadászgépek esedékes cseréje érdekében pedig 2019-ben megállapodás született 32 db F-35 amerikai gyártmányú harci gép beszerzéséröl, összesen 6,5 milliárd dollár értékben (Reuters, 2019).

2 A FTSE Russell a globális pénzügyi piacokról szolgáltat információkat, adatokat, elemzéseket. A vállalkozás 100 százalékos tulajdonosa a Londoni Értéktőzsde (London Stock Exchange Group, LSEG) és az Információszolgáltatási Divízió (Information Services Division) része (FTSE Russel).

${ }^{3}$ A céget végül a baszk CAF vásárolta fel. 
Konvergencia vagy közepes jövedelmi csapda? - Lengyelország lehetőségei...

ruházattal foglalkozó LPP $(H V G, 2018)$. Kiemelendö, hogy a lengyel, illetve a magyar tőzsdén jegyzett ökoinnovatív cégek pénzügyi jövedelmezősége meghaladja az e téren nem aktívak hasonló mutatóit, ami azt jelenti, hogy a régióban is vannak aktív, innovatív és tőkeerős cégek, amelyek mintaként szolgálhatnak a feltörekvő kis- és középvállalkozók számára. Fontos ugyanakkor megjegyezni, hogy az ökoinnovatívabb cégek a nagyobb vállalkozások közül kerülnek ki (Przychodzen és Przychodzen, 2015).

A cikkben Lengyelország helyzetét, gazdasági lehetőségeit elemzem. A tanulmány következő fejezetében az ország helyzetét az összehasonlító közgazdaságtan eszközeivel vizsgálom, míg az azt követő fejezetben a nemzetgazdaság föbb kérdéseire (energiabiztonság, közlekedés, európai integráció) térek ki. A tanulmány végén összegzem az eredményeket.

\section{A lengyel intézményrendszer tipizálása}

„A kapitalizmus nem merev, egyöntetü rendszer. Számos mutációja van, amelyek közül a történelem szelektál" (Kornai, 1999, 595. o.). A különböző modellek fejlődését, sikerességét, illetve annak okait kutatja az összehasonlító kapitalizmus (comparative capitalism). A kapitalizmusvariációk (Varieties of Capitalism) koncepciójának alapja az, hogy a piacgazdaság müködési mechanizmusait jelentős mértékben meghatározzák az ország intézményei és szervezetei (Hall-Soskice, 2004). Intézmények alatt a formális és informális szabályok azon rendszerét értjük, amelyet normális körülmények között a gazdasági aktorok normatív, kognitív vagy anyagi okokból követnek. Az intézmények az előbbiekhez kapcsolódva azon entitások, amelyek szabályai hozzájárulnak a politikai gazdaság intézményeihez (North, 1990, 3. o. Idézi: Hall - Soskice, 2004).

A kapitalizmusvariációk koncepciójának kidolgozásában Andrew Schonfield végzett úttörő munkát, azonban a terület első nagyobb volumenű összefoglaló mủvét Peter Hall és David Soskice állították össze (Nölke és Vliegenthart, 2009). A modell az államot tekinti elemi területi egységnek, ugyanis az identitás és ehhez kapcsolódóan az intézmények is eltérőek lehetnek kisebb területi egységenként, a jogszabályi környezet azonban legfeljebb az alkotmányos régiók szerint változik. Mivel a piacgazdaság belső szerkezete az elemzés tárgya, a koncepció fókuszpontjában a vállalatok állnak (Hall - Soskice, 2004).

A modell a kapitalizmus két ideáltípusát, a koordinált piacgazdaságot (Coordinated Market Economy, CME) és a liberális piacgazdaságot (Liberal Market 
Economy, LME) különíti el. A szerzők öt olyan paramétert emelnek ki, amelyek a két ideáltípust elkülönítik, ezek 1. a pénzügyi elosztórendszer, 2. a vállalatirányítás, 3. az iparági kapcsolatok, 4. az oktatás, valamint 5. az innovációk transzfere (HallSoskice, 2004). Az ideáltípusok főbb jellemzőit az 1. táblázatban mutatom be.

1. táblázat

\section{A különböző kapitalizmusvariációk főbb ismérvei}

\begin{tabular}{|c|c|c|c|c|}
\hline & $\begin{array}{l}\text { Liberális } \\
\text { piacgazdaság } \\
(\mathrm{LME})\end{array}$ & $\begin{array}{l}\text { Koordinált piac- } \\
\text { gazdaság (CME) }\end{array}$ & $\begin{array}{l}\text { Függő piacgazda- } \\
\text { ság (DME) }\end{array}$ & $\begin{array}{l}\text { Kétszeresen függő piac- } \\
\text { gazdaság (DDME) }\end{array}$ \\
\hline $\begin{array}{l}\text { Koordinációs } \\
\text { mechanizmus }\end{array}$ & $\begin{array}{l}\text { Piaci verseny } \\
\text { és formális } \\
\text { szerződések }\end{array}$ & $\begin{array}{l}\text { Vállalatok közötti } \\
\text { kapcsolatok és } \\
\text { szervezetek }\end{array}$ & $\begin{array}{l}\text { Transznacionális } \\
\text { vállalatok belső } \\
\text { hierarchiájától } \\
\text { való függés }\end{array}$ & $\begin{array}{l}\text { Transznacionális vállalatok } \\
\text { belső hierarchiájától, illet- } \\
\text { ve kormányzati kapcsola- } \\
\text { toktól való függés }\end{array}$ \\
\hline $\begin{array}{l}\text { Beruházások } \\
\text { finanszírozásá- } \\
\text { nak forrása }\end{array}$ & $\begin{array}{l}\text { Bel- és külföl- } \\
\text { di tőkepiacok }\end{array}$ & $\begin{array}{l}\text { Hazai bankok, } \\
\text { belső források }\end{array}$ & $\begin{array}{l}\text { FDI és külföldi } \\
\text { tulajdonú bankok }\end{array}$ & $\begin{array}{l}\text { FDI és külföldi tulajdonú } \\
\text { bankok, továbbá központi } \\
\text { költségvetés, EU-s forrá- } \\
\text { sok, illetve állami bankok }\end{array}$ \\
\hline $\begin{array}{l}\text { Vállalatirá- } \\
\text { nyítás }\end{array}$ & $\begin{array}{l}\text { Külső } \\
\text { kontroll/ } \\
\text { széles körü } \\
\text { tulajdonosi } \\
\text { struktúra }\end{array}$ & $\begin{array}{l}\text { Belső kontroll/ } \\
\text { koncentrált tulaj- } \\
\text { donlás }\end{array}$ & $\begin{array}{l}\text { Transznacionális } \\
\text { vállalkozások } \\
\text { központjának } \\
\text { kontrollja }\end{array}$ & $\begin{array}{l}\text { Transznacionális vállal- } \\
\text { kozások központjának } \\
\text { kontrollja, közvetett és } \\
\text { közvetlen állami kapcso- } \\
\text { latok szükségessége, köz- } \\
\text { pontilag irányított állami } \\
\text { vállalatok }\end{array}$ \\
\hline $\begin{array}{l}\text { Ipari kapcso- } \\
\text { latok }\end{array}$ & $\begin{array}{l}\text { Piaci alapú, } \\
\text { kevés kollek- } \\
\text { tív szerződés }\end{array}$ & $\begin{array}{l}\text { Korporatista, } \\
\text { konszenzusos, } \\
\text { iparági vagy or- } \\
\text { szágos kollektív } \\
\text { szerződések }\end{array}$ & $\begin{array}{l}\text { Képzett munka- } \\
\text { erő megtartása, } \\
\text { vállalati szintü } \\
\text { szerződések }\end{array}$ & $\begin{array}{l}\text { Képzett munkaerő meg- } \\
\text { tartása, vállalati szintű } \\
\text { szerződések, erős állami } \\
\text { befolyás, széles körű és } \\
\text { centralizált közszféra }\end{array}$ \\
\hline Oktatás & $\begin{array}{l}\text { Általános } \\
\text { képesség, } \\
\text { jelentős K+F } \\
\text { ráfordítás }\end{array}$ & $\begin{array}{l}\text { Vállalati vagy } \\
\text { iparági specifikus } \\
\text { tudás, szakmai } \\
\text { képzés }\end{array}$ & $\begin{array}{l}\text { Továbbképzések } \\
\text { korlátozott finan- } \\
\text { szírozása }\end{array}$ & $\begin{array}{l}\text { Továbbképzések korláto- } \\
\text { zott finanszírozása, domi- } \\
\text { náns állami szerep }\end{array}$ \\
\hline $\begin{array}{l}\text { Innovációk } \\
\text { transzfere }\end{array}$ & $\begin{array}{l}\text { Piaci alapon, } \\
\text { formális } \\
\text { szerződések } \\
\text { szerint }\end{array}$ & $\begin{array}{l}\text { Jelentős a közös } \\
\text { műveletek és } \\
\text { a szervezetek } \\
\text { szerepe }\end{array}$ & $\begin{array}{l}\text { Transznacionális } \\
\text { vállalatokon belü- } \\
\text { li transzferek }\end{array}$ & $\begin{array}{l}\text { Transznacionális vállala- } \\
\text { tokon belüli transzferek, } \\
\text { állami erőforrások, koordi- } \\
\text { náció és transzfer }\end{array}$ \\
\hline
\end{tabular}


Konvergencia vagy közepes jövedelmi csapda? - Lengyelország lehetőségei...

\begin{tabular}{lllll}
\hline & $\begin{array}{l}\text { Liberális } \\
\text { piacgazdaság } \\
\text { (LME) }\end{array}$ & $\begin{array}{l}\text { Koordinált piac- } \\
\text { gazdaság (CME) }\end{array}$ & $\begin{array}{l}\text { Függő piacgazda- } \\
\text { ság (DME) }\end{array}$ & $\begin{array}{l}\text { Kétszeresen függő piac- } \\
\text { gazdaság (DDME) }\end{array}$ \\
\hline $\begin{array}{l}\text { Komparatív } \\
\text { elönyök }\end{array}$ & $\begin{array}{l}\text { Radikális } \\
\text { innováció }\end{array}$ & $\begin{array}{l}\text { Tőkejavak } \\
\text { inkrementális } \\
\text { innovációja }\end{array}$ & $\begin{array}{l}\text { Részben } \\
\text { sztenderdizált } \\
\text { ipari javak össze- } \\
\text { szerelése }\end{array}$ & $\begin{array}{l}\text { Részben sztenderdizált } \\
\text { ipari javak összeszerelése, } \\
\text { gazdaságpolitikák és poli- } \\
\text { tikai prioritások könnyebb } \\
\text { megvalósítása, kedvező }\end{array}$ \\
& & & $\begin{array}{l}\text { környezet államilag ked- } \\
\text { vezményezett szektorok }\end{array}$ \\
& & & számára \\
\hline
\end{tabular}

Forrás: LME, CME és DME oszlopok esetén: Nölke és Vliegenthart [2009], 680. o., DDME esetében: Bank [2017], 33. o.

A koordinált piacgazdaság (CME) elsősorban Németországot, Ausztriát, de bizonyos specialitásokkal együtt Japánt is jellemzi. Ezen országokban kitüntetett szerep jut az informális szerződésekre, amelyek a szereplők, így a munkavállalók, állam és a vállalatok számára egyaránt biztonságot és kiszámíthatóságot jelentenek. Ennek következtében a munkavállaló az állami oktatási rendszerben a piacon hasznosítható, versenyképes tudást kap, az ágazati vagy országos kollektív szerződések pedig garantálják a munkakörülményeket és a béreket, ezáltal a munkavállaló hoszszabb távon járulhat hozzá a cég fejlődéséhez, sikeréhez. A szerződés másik oldala, hogy a vállalatok krízis esetén a megtérülési rátát csökkentik és nem a (munkaerő) költségeket, ami hozzájárul a piaci részesedés növeléséhez. Ezt a biztonságot a vállalatok koncentrált tulajdonosi szerkezete garantálja, amelyben nem ritka a kereszttulajdonlás vagy akár az állami részvétel sem. Fontos ismérv továbbá, hogy mivel a béreket legalább ágazati szinten állapítják meg, a munkaerő vándorlása nem jellemző. Az iparági legjobb gyakorlatok rendszerint az iparági együttmüködések, valamint a sztenderdizáció által terjednek el (Hall - Soskice, 2004).

A koordinált piacgazdaság számos hasonlóságot mutat Camagni [1995] innovációs miliővel kapcsolatos modelljével, amelyben a visszamaradott régiókban először a szektorok közötti szinergiákat aknázzák ki, majd a sikeres gyakorlatok diffúziójára kerül sor, amelyet a fejlett és hagyományos technológiák „keverése” (blending) követ. A negyedik lépés a meglévő termékek/technológiák újszerü alkalmazása, az ötödik a kisebb léptékủ (inkrementális) innovációk végrehajtása, végül pedig a radikális innovációkra kerül sor. A koordinált piacgazdaság ezen logika utolsó előtti lépcsőjét, a meglévő termékek inkrementális fejlesztését jelenti, amelyet az iparági szereplők a társadalmi intézményeken alapuló együttmüködése tesz lehetővé. 
A liberális piacgazdaság (LME) ezzel szemben a piaci koordinációra helyezi a hangsúlyt. A modellben szinte kizárólagos a formális szerződések alkalmazása, ritkák az iparági kollektív szerződések, a vállalati összefonódások pedig tiltottak. A kollektív szerződések hiánya következtében gyakori a munkaerő vándorlása és a bérverseny, amelyet a generális tudást fókuszba helyező oktatási rendszer is támogat. A munkaerő nagyobb mobilitása, valamint a bérverseny következtében a modell elsősorban a radikális innovációknak kedvez (Hall - Soskice, 2004).

A keretrendszer legfőbb kritikája lehet, hogy a fejlett nyugati országok elemzésére készült, a kevésbé fejlett gazdaságokra való alkalmazása túlnyúlik a modell keretein (Bohle és Greskovits, 2012). A kritika feloldására a kutatók a kapitalizmus új változatainak feltárására vállalkoztak. Ilyen a Nölke és Vliegenthart [2009] által a kelet-közép-európai államokra (Csehország, Lengyelország, Magyarország és Szlovákia) kidolgozott harmadik kapitalizmusvariáció, amelyet függö piacgazdaságnak (Dependent Market Economy, DME) neveznek. A szerzők szerint a régió számára speciális helyzetet eredményezett, hogy a KGST felbomlását követően a nyugati orientáció mellett döntött. Az államok piacnyitását követően a helyi tőkeés szakértelemhiány miatt elsősorban a nyugati transznacionális vállalatok vettek részt a szocialista vállalatok privatizálásában, ami a gazdaság szerkezetét az évtized végére alapvetően változtatta meg. A beáramló külföldi tőke segített a tranzíciós válság leküzdésében és gyors gazdasági növekedést okozott - ezért is nevezi Leven [2011] a V4-eket, valamint Romániát és Bulgáriát a „fejlett keletnek” (Developed East). Fontos kiemelni, hogy a modellben az FDI megkülönböztetett szerepét nem a gazdaságban betöltött relatív jelentősége, hanem a külföldröl beáramló és a hazai tőkekihelyezések aszimmetriája okozza (lásd a 2. táblázatot). A működőtőkeállomány tekintetében a V4-országok között jelentős eltérések mutatkoznak - míg Lengyelország a többi országhoz képest alacsony FDI-állományok alapján kifejezetten zárkózottnak tekinthető, addig Magyarország esetében a magas belföldi FDIállomány mellett viszonylag jelentős tőkekihelyezés is mutatkozik. Ugyanakkor az országokban befektetett külföldi tőke valamennyi esetben többszörösen meghaladja az országokból kihelyezett tőke mennyiségét, ami a régió feltörekvő jellegét mutatja. 
Konvergencia vagy közepes jövedelmi csapda? - Lengyelország lehetőségei...

2. táblázat

A múködőtőke-állomány GDP-hez viszonyított aránya a V4-országokban, illetve az Európai Unióban

\begin{tabular}{|c|c|c|c|c|c|}
\hline & & 1995 & 2016 & 2017 & 2018 \\
\hline \multirow{3}{*}{ Szlovákia } & Beáramlott FDI-állomány & 6,5 & 52,9 & 58,3 & 53,6 \\
\hline & Kiáramlott FDI-állomány & 0,7 & 2,9 & 3,6 & 3,5 \\
\hline & $\begin{array}{l}\text { Beáramlott és kiáramlott FDI } \\
\text { aránya }\end{array}$ & 9,29 & 18,24 & 16,19 & 15,31 \\
\hline \multirow{3}{*}{ Csehország } & Beáramlott FDI-állomány & 12,3 & 62,5 & 72,2 & 64 \\
\hline & Kiáramlott FDI-állomány & 0,6 & 10 & 15 & 14,4 \\
\hline & $\begin{array}{l}\text { Beáramlott és kiáramlott FDI } \\
\text { aránya }\end{array}$ & 20,50 & 6,25 & 4,81 & 4,44 \\
\hline \multirow{3}{*}{$\begin{array}{l}\text { Lengyelor- } \\
\text { szág }\end{array}$} & Beáramlott FDI-állomány & 5,6 & 40 & 45,3 & 39,6 \\
\hline & Kiáramlott FDI-állomány & 0,4 & 5,9 & 5,7 & 4,9 \\
\hline & $\begin{array}{l}\text { Beáramlott és kiáramlott FDI } \\
\text { aránya }\end{array}$ & 14,00 & 6,78 & 7,95 & 8,08 \\
\hline \multirow{3}{*}{$\begin{array}{l}\text { Magyaror- } \\
\text { szág }\end{array}$} & Beáramlott FDI-állomány & 24,4 & 64 & 64,9 & 57 \\
\hline & Kiáramlott FDI-állomány & 0,6 & 19,9 & 21,5 & 18,6 \\
\hline & $\begin{array}{l}\text { Beáramlott és kiáramlott FDI } \\
\text { aránya }\end{array}$ & 40,67 & 3,22 & 3,02 & 3,06 \\
\hline \multirow{3}{*}{$\begin{array}{l}\text { Európai } \\
\text { Unió }\end{array}$} & Beáramlott FDI-állomány & 13,1 & 52,1 & 58,6 & 53,9 \\
\hline & Kiáramlott FDI-állomány & 17,6 & 62 & 68,1 & 61,4 \\
\hline & $\begin{array}{l}\text { Beáramlott és kiáramlott FDI } \\
\text { aránya }\end{array}$ & 0,74 & 0,84 & 0,86 & 0,88 \\
\hline
\end{tabular}

Forrás: UNCTAD [2019a], saját szerkesztés.

Az országok duális gazdaságának - vagyis a tőkeszegény és exportra korlátozottan képes hazai tulajdonú kis- és középvállalkozásokra, valamint az exportra termelő transznacionális vállalatokra osztható gazdaságnak - egyszerre oka és következménye a külföldi befektetésekre alapozott gazdasági fejlődési modellnek. Egyrészt a KGST felbomlását követően az országokban legfeljebb néhány olyan vállalat volt, amely rendelkezett piacképes termékkel, elegendő tőkével, valamint menedzsmentismerettel, amely a nyugati piacokra való termelést, illetve befektetést lehetővé tette volna. Ezen feltehetően a nyugati országok piacvédő intézkedései is súlyosbíthattak. Másrészt a külföldi múködő tőkét letelepíteni kívánó gazdaságpolitika követése miatt kevesebb állami gazdaságfejlesztési forrás jut a hazai kis- és középvállalati szektorra. 
A függő piacgazdaság versenyelőnye a magasan képzett és a magországokhoz képest olcsó munkaerőben rejlik, ami alkalmassá teszi a termelési feladatok ellátására. Ezen országok gazdaságai különösen erősen támaszkodnak a külföldröl beáramló működő tőkére. Tekintettel arra, hogy a külföldi tőke a közepes hozzáadott értékủ munkafolyamatokat szervezi ki, az országok innovációs potenciálja rendszerint alacsony, továbbá hajlamosak lehetnek bennragadni a közepes fejlettségủ országok kategóriájában (middle income trap). A helyzetet súlyosbíthatja, ha az oktatási rendszer túlzottan egyes iparági igények vagy a formális kvalifikációk teljesítésére törekszik. Ebben az esetben ugyanis kitörési lehetőség csupán a külföldi továbbtanulás vagy a magániskolák által képzelhető el, az állami oktatásban részt vevők pedig a nemzetgazdaságot nem képesek kiszabadítani a közepes fejlettségből (Tarlea-FreybergInan, 2018).

A függő piacgazdasági modellt Bank [2017] annyiban egészíti ki, hogy a magyarországi piacgazdaság függése kettős, ugyanis a gazdasági folyamatokat nemcsak a transznacionális vállalatok, hanem a széles körü és egyes esetekben fokozódó állami szerepvállalás is torzítja.

Farkas Beáta [2017] Hall - Soskice [2004] vagy Nölke és Vliegenthart [2009] elemzéseitől eltérően az Európai Unió valamennyi országát egységes modellben vizsgálta. Eredményei alapján a kelet-közép-európai posztszocialista államok ugyan heterogén csoportot alkotnak, a magállamoktól való fejlettségbeli távolság mégis nagyobb, mint a közöttük levő eltérések. Összegzésként tehát megállapítható, hogy ha a V4-ek, így Lengyelország esetében a külföldi müködő tőke gazdaságban betöltött jelentős szerepét modellképző ismérvként nem is fogadjuk el, az EU kelet-középeurópai új tagállamai az EU magországaitól mindenképpen szignifikánsan eltérő kapitalista berendezkedést alakítottak ki.

\section{A nemzetgazdaság kulcsterületeinek elemzése}

A lengyel nemzetgazdaságból három kulcsterületet emelünk ki, olyanokat, amelyek az európai integráció szempontjából fontosak: a gazdaság struktúráját, a közlekedési infrastruktúrát, valamint az energiabiztonságot. Valamennyi terület esetében megbízható forrásokra támaszkodva kíséreljük meg elemezni Lengyelország jelenlegi helyzetét és jövőképét. 
Konvergencia vagy közepes jövedelmi csapda? - Lengyelország lehetőségei...

Az európai integráció

Kolodko [2017] szerint Lengyelország számára az euró bevezetése lehetőség a magrégióhoz való kapcsolódásra. A lengyel eurónak különös jelentőséget ad, hogy a brexittel ${ }^{4}$ jelentős gazdasági tényező távozik az EU-ból, így a legnagyobb, nem eurót használó tagállam valutaközösséghez való csatlakozása az országnak különös súlyt adna.

A Világbank adatai alapján a lengyel export 56 százaléka, míg az import

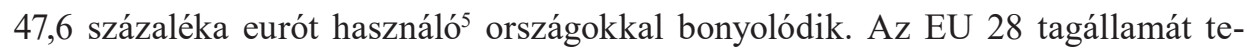
kintve a két érték 78,9, illetve 59,55 százalék. Amennyiben nemcsak az országokat, hanem az euróban denominált kereskedelmet tekintjük, akkor a külkereskedelem kb. 70 százaléka euróban történik. A lengyel euró bevezetése jelentős mértékben csökkenthetné a devizakockázatot, ami az adminisztratív terhek csökkenésével együtt tíz év alatt csaknem 15 százalékos GDP-növekedést okozhatna, jelentős mértékben javítva a lengyel állampolgárok életszínvonalát. További gazdasági elönyként említhető a devizatartalék tartásának csökkenő terhe, valamint a valutaunió nyomán az államadósság alacsonyabb költsége (Kolodko, 2017). A valutaunióhoz történő csatlakozás elleni egyik legfőbb érv, hogy a lépéssel az ország feladni kényszerül független monetáris politikáját. Ugyanakkor a nemzeti valutával rendelkező keletközép-európai államok monetáris politikája már ma is csupán részben független. Goczek és Partyka [2019] kimutatta, hogy hosszú távon az eurózónán kívüli tagállamokban a kamatlábak követik az eurózónában tapasztalható kamatlábakat - például az eurózóna reál kamatszintjének 1 százalékos változása esetén az eurózónán kívüli kelet-közép-európai EU-tagállamokban és Norvégiában a kamatszint azonos irányú, 0,75-0,8 bázispontos változása várható. Ez azt jelenti, hogy az integráció költségei a becsültnél alacsonyabbak. A V4-országok (kivéve Szlovákia) központi bankjai, illetve az Európai Központi Bank referenciakamat-rátái rendre alacsony kamatszintet határoztak meg és tartanak fenn a gazdasági növekedés elősegítése céljából. Habár Csehországban 2018 augusztusa óta több kamatemelést is végrehajtottak, ezekkel együtt is illeszkedik a magyar ( 0,9 százalék), illetve a lengyel (1,5 százalék) értékekhez (lásd az 1. ábrát).

${ }^{4}$ Cikkünk írásakor még egyaránt elképzelhető a brexit egyoldalú visszavonása és a hard brexit is.

${ }^{5}$ Az eurózónán kívüli, de eurót használó országként tekintünk Montenegróra, ahol a lengyel külkereskedelem aránya az import, illetve az export 0,01, illetve 0,02 százalékát teszi ki. Hasonló Koszovó státusza is, de az országra nem áll rendelkezésre adat. Bosznia-Hercegovinát az elemzésből elhagytuk, ugyanis nem eurót, hanem a német márkához - így pedig az euróhoz - fixen rögzített konvertibilis márkát használ. A külkereskedelem volumene ebben az esetben is elhanyagolható. 


\section{A V4-országok (kivéve Szlovákia) és az Európai Központi Bank referenciakamat-rátái}

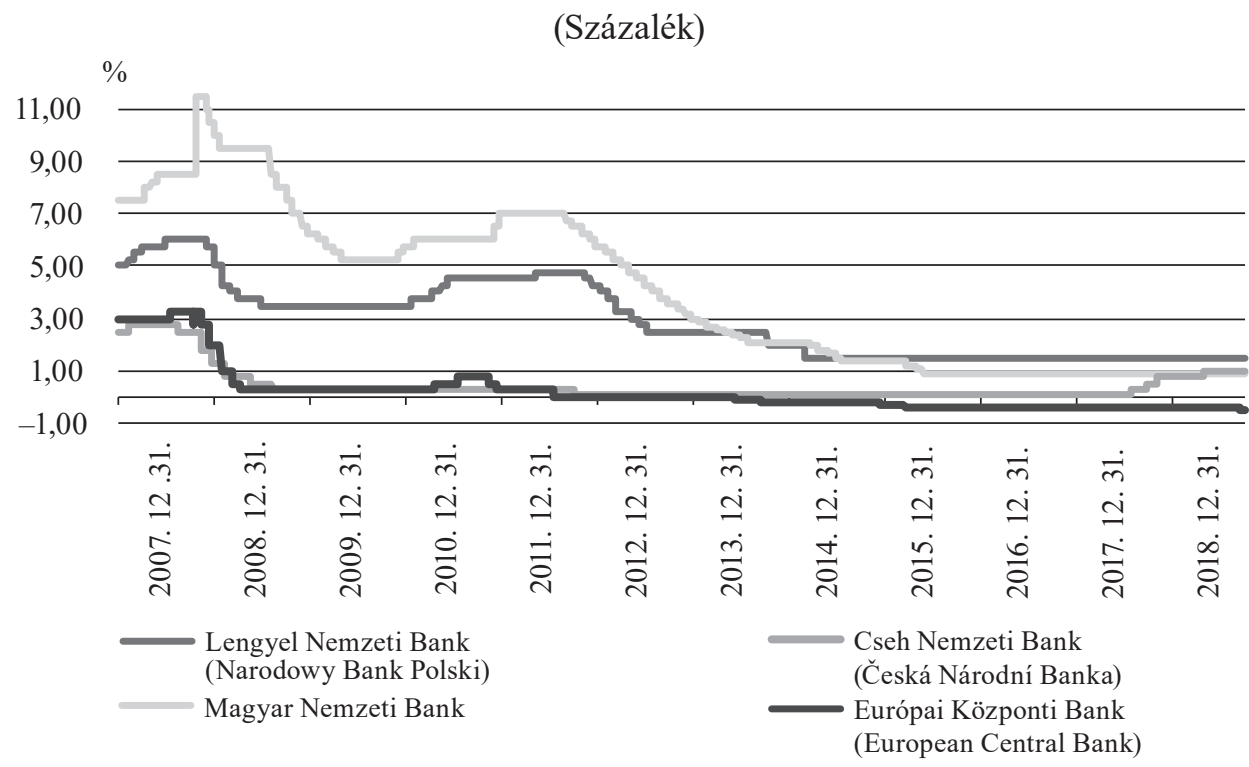

Forrás: Központi bankok adatai alapján saját szerkesztés.

Ugyanakkor a lengyel lakosság nem támogatja az euró bevezetését - az Eurobarométer adatai alapján 2018-ban csak a népesség 48 százaléka európárti. Ez a 2017. évi 43 százalékhoz képest emelkedést jelent, mégsem beszélhetünk erőteljes társadalmi támogatottságról. Kolodko [2017] szerint ugyanakkor a közvélemény erős kormányzati kampánnyal a bevezetés mellé állítható. Kérdéses azonban, hogy a kormányzati szándék megvan-e. A lengyel igazságügyi reform - amelynek keretében az alkotmánybíróság tagjait a kormánypárt tagjaival töltötték fel, továbbá a legfelsőbb bíróságot az igazságügyi minisztérium alá sorolták - nem járul hozzá a mélyebb integráció megvalósításához (Kovács-Scheppele, 2018).

Az FDI-tól függő piacgazdaságok számára a nemzeti valuta megőrzése különös jelentőségü, ugyanis annak leértékelése a munkaerőköltség külföldi devizában kifejezett értékén keresztül javíthatja a versenyképességet, illetve támogatja az exportot. Ugyanakkor a nemzeti valutát használó visegrádi országok között a nemzeti valuta jelentősebb leértékelésére kizárólag Magyarország esetében került sor - Lengyelor- 
Konvergencia vagy közepes jövedelmi csapda? - Lengyelország lehetőségei...

szág és föként Csehország esetében a złoty, illetve a korona árfolyama kisebb kilengésektől eltekintve hosszabb ideje állandónak tekinthető (lásd a 2. ábrát).

\section{A V4 országok nemzeti valutáinak euróhoz viszonyított árfolyama}

(2007. 12. 31. = 100 százalék)

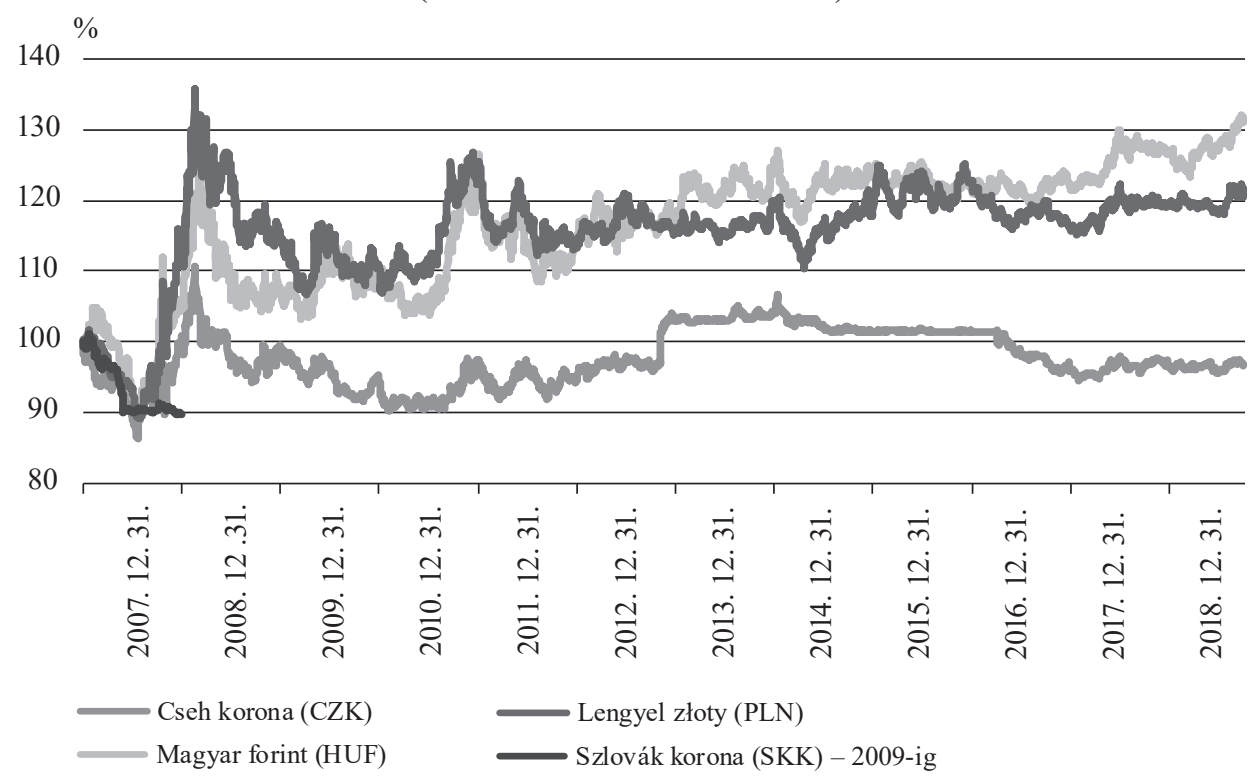

Forrás: Európai Központi Bank.

A lengyel kormány intézkedései következtében több kötelezettségszegési eljárás zajlik az országgal szemben, továbbá aktiválták az Európai Unió Müködéséről szóló Szerződés (EUMSZ) 7. cikke szerinti eljárást, ami az ország EU-ban való elszigetelődését okozhatja. Habár a kritikák következtében a kormány mérsékeltebb hangvételre váltott, egyesek már az EU-ból való kiválás (ún. „polexit”) előkészítését látják (Der Spiegel, 2018b). Ugyanakkor véleményem szerint a polexit két okból sem reális forgatókönyv. Egyrészt a lengyel kormánypárt (PiS) populista politikát követ. Ez értelmezésünkben azt jelenti, hogy a népszerüség fenntartása és növelése érdekében 1. a párt elveit rugalmasan változtatja, 2. a komplex jelenség túlzott egyszerüsítésével, valamint nacionalista szólamokkal tematizálja a közbeszédet (Heinisch, 2019). A jelenséget jól mutatja, hogy a PiS a 2019. májusi európai parlamenti választá- 
sokat megelőző kampányban már sokkal inkább az EU-n belüli, mintsem az EU elleni harcosként határozta meg magát. Az eredmények alapján ez az eltávolodás az európai szélsőjobb kommunikációs paneljeitől a PiS számára választási győzelmet jelentett (Der Spiegel, 2019a), továbbá Lengyelország delegáltja kapta a 2019-ben megalakuló új Erópa Bizottságban a kiemelten fontos agrárbiztosi pozíciót (Der Spiegel, 2019b). Másrészt az EU-n belül elszigetelödött, vagy esetlegesen az EUból kilépő (lásd: „,polexit”) Lengyelország az ősi ellenség Oroszország és a világ jelenlegi legnagyobb piaca közé ékelődne, egyaránt elzárva szárazföldi, tengeri és légi kijárataitól. Mindeközben a hagyományosan erős amerikai-lengyel kapcsolatok Trump elnök Amerika-központú külpolitikája, valamint az USA földrajzi távolsága következtében egy esetleges polexitet követően meglehetősen alacsonyak lennének.

A 2019-es év a lengyel kormány számára a brexit miatt további kockázatokat jelenthet, ugyanis a rendezetlen kilépés esetén kérdéses lehet a Nagy-Britanniában dolgozó kb. egymillió lengyel állampolgár további sorsa.

A brexit ugyanakkor Lengyelország számára két okból is kitörési lehetőséget jelent. Egyrészt Lengyelország versenyképes alternatíva a Nagy-Britanniából távozó vállalatok számára, ugyanis a lengyelek kb. 70 százaléka legalább egy idegen nyelvet beszél (Eurostat, 2017), továbbá a más európai nagyvárosokhoz (lásd: Frankfurt am Main, Párizs, München stb.) képest több irodai kapacitás áll rendelkezésre, van lehetőség azok bővitésére, valamint a bérleti díjak is sokkal kedvezőbbek. Másrészt jelentős számú angolul jól beszélő, liberális piacgazdaságban érvényesülni képes munkavállaló térne vissza, amennyiben a brexit érintené a lengyel munkavállalók egy részének vagy egészének a Nagy-Britanniában való tartózkodási jogát. Ök a külföldön megszerzett know-how segítségével modernizálhatnák a lengyel intézményrendszert, ami lehetővé tenné a kis- és középvállalati szektor versenyképességének erősítését.

Gazdasági struktúra

Lengyelország volt az egyetlen EU-tagállam, amely a 2008-as gazdasági világválságot gazdasági recesszió nélkül vészelte át (Leven, 2011), amit a hazai piac, valamint a bankrendszer jellemzőivel magyarázhatunk.

A belső fogyasztás kelet-közép-európai EU-tagországokhoz mérten magasabb aránya, valamint a gazdaság nagyobb zártsága fokozza a gazdaság külső gazdasági sokkokkal szembeni ellenállóságát (A gazdasági válság..., 2010). A lengyel vállalkozások számára hatalmas lehetőséget jelent, hogy Lengyelország nagy területü, 
Konvergencia vagy közepes jövedelmi csapda? - Lengyelország lehetőségei...

lakossága etnikailag homogén, nyelve eltér a szomszédjaitól, továbbá egyedi kulturális örökséggel rendelkezik (Leven, 2011). Ezen adottságok a lokalizáció költségei következtében emelik a külföldi vállalkozások belépési korlátait, míg a megfelelő méretü belső piac lehetővé teszi a nemzetközi piacon is versenyképes nemzeti bajnok cégek létrejöttét. A nemzetközi piacon aktív és sikeres lengyel vállalkozásokra jó példa a közösségi közlekedési jármüveket (például buszok, villamosok stb.) gyártó Solaris ( $H V G, 2016)$, vagy a ruházattal foglalkozó LPP $(H V G, 2018)$. A lengyel cégek nemzetközi terjeszkedését jól mutatja, hogy 2018 és 2019 között a Magyarországra történő export (forintban számolva) csaknem háromszorosára emelkedett (G7, 2019). Ugyanakkor figyelemre méltó, hogy az UNCTAD bilaterális FDI-statisztikái (UNCTAD, 2019b) szerint a magyar vállalkozások 2012-ig csaknem kétszer annyi működő tőkét helyeztek ki Lengyelországba (1239 millió dollár), mint a lengyelek Magyarországon (637 millió dollár).

Fontos kiemelni, hogy magyarországiakhoz hasonlóan a lengyel nemzeti bajnok vállalatok számára is gyakran adódik egy felső növekedési korlát, ami után a tulajdonosok rendszerint a cég értékesítése mellett döntenek. Az elmúlt évtizedböl ilyen eset a Solaris felvásárlása 2018-ban, de hasonló történt a magyar Fornettivel, a Szentkirályival, vagy a Sziget Fesztivált is szervező céggel. A vásárló valamennyi esetben szakmai befektető, mégis úgy tűnik, a kelet-közép-európai régió országai csak ritkán tudnak kitermelni saját multinacionális vállalatokat.

A helyzet kezelésére Lux [2017] a versenyképes hazai vállalkozások felépítésére az iparpolitikai és állami támogatási lehetőségek maximális kihasználását javasolja. A koordinált piacgazdaságokban megszokott módon a többgenerációs és növekedésorientált családi vállalkozások - megfelelő menedzsmenttudás és tőkeerő mellett - a nemzetközi piacon is versenyképesek lehetnek, ennek előnye kettős. Egyrészt a kritikus tömeg elérését követően sem feltétlen a szakmai befektetők részére történő értékesítés, hanem a tőzsdére lépés lehet az alternatíva a továbblépésre. Másrészt a családi vállalkozásokat övező nagyobb bizalom hozzájárulhat az intézményrendszer konszolidálásához, a hosszabb távú tervezéshez.

A gazdaság versenyképességét fokozza, hogy a bankrendszert hazai szereplök dominálják, a külföldi tulajdonosok pedig a hosszú távú megtérülést tartják szem elött, amelynek keretében átadják a magországokban felhalmozott know-how-t is. Szintén jelentős előnyt jelent - föként a magyar, a horvát, illetve a román bankrendszerekkel szemben -, hogy a lakossági jelzáloghitelezést korábban is hazai devizában, złotyban denominálták, aminek következtében a devizahitelezés kockázatai a bankrendszeren kívülre kerültek. Érdekes módon fejletlen végrehajtási gyakorlatai 
is hozzájárultak a válságállósághoz, ugyanis a hitelek tömeges bedőlésének elmaradásával a lakásárak az egyéb kelet-közép-európai országokhoz képest kevésbé csökkentek, ami lassította a válság terjedését (Leven, 2011).

Leven [2011] további előnyként emeli ki a gazdaság diverzifikáltságát. Míg Szlovákia vagy Magyarország erőteljesen kitett a külföldi, jellemzően német autóipari múködő tőkének és a piacnak, addig a lengyel export több iparág között oszlik meg. Minden lehetősége ellenére azonban a lengyel gazdaság is nettó működőtőkeimportőr. Az UNCTAD 2019-es adatai alapján a belföldi müködőtőke-állomány a GDP csaknem 40 százalékát teszi ki, míg a lengyel cégek külföldi befektetései a GDP 4,9 százalékára rúgnak (lásd a 2. táblázatot). A statisztikák tanúsága szerint az olló tovább nyílik, ugyanis a tőkebeáramlás rendre meghaladja a GDP 10 százalékát, míg a kiáramlás - 2016 kivételével - 2005 és 2018 között évi 3 százalék körül alakult (UNCTAD, 2019a). Az adatok alapján e téren alátámasztható Lengyelország függő piacgazdasági besorolása.

Közlekedési infrastruktúra

Lengyelország hajózási lehetőségei elsősorban a Balti-tengerre korlátozódnak. Az ország tengeri kikötői közül négy ${ }^{6}$ a transzeurópai közlekedési hálózat (TransEuropean Transport Network, TEN-T) maghálózatához (core), egy pedig a kiegészítő (comprehensive) hálózatához tartozik. TEN-T jelentőségủ belvízi útvonal Lengyelországban csak az Oderán van, amely Berlin, illetve Magdeburg felé nyújt eljutási lehetőséget. Ez ugyan lehetővé teszi a főbb közép-európai desztinációk (Prága, Bécs, Budapest stb.) elérését, azonban az óceánok felől ez vélhetően kedvezőbb módon kivitelezhető Hollandiából a Rajnán, vagy Hamburg irányából az Elbán keresztül. Az észak-déli irányú eljutás a közúti és a vasúti szállítási módokkal szintén lényegesen kisebb kitérökkel megoldható.

Mind a közúti, mind a vasúti infrastruktúra terén elsősorban a kelet-nyugati irány a meghatározó. Ennek oka elsősorban az, hogy az észak-déli folyosók a Kárpátokon történő átkelést teszik szükségessé.

Lengyelországban a 2007 és 2013 közötti európai költségvetési periódusban 1500 km gyorsforgalmi út épült, ami a hálózat megduplázódását jelentette. A 2012re elért $0,44 \mathrm{~km} / 100 \mathrm{~km}^{2}$ gyorsforgalmi út sürüsége azonban így is elmarad mind az EU-15, mind az új tagországok átlagától ${ }^{7}$ (PwC, 2016). A fejlesztések megvalósítása

${ }^{6}$ Świnoujście, Szczecin, Gdynia és Gdańsk.

7 Az EU-15 esetén ez az érték 2,73 km/100 km², míg az új tagállamok (kivéve Ciprus és Málta) esetében $0,97 \mathrm{~km} / 100 \mathrm{~km}^{2}$. 
Konvergencia vagy közepes jövedelmi csapda? - Lengyelország lehetőségei...

során - az egyéb nemzetgazdasági célok mellett - jelentős súllyal eshetett latba a 2012-es közös lengyel-ukrán labdarúgó Európa-bajnokság megrendezése is.

A vasúti infrastruktúra terén a legnagyobb kihívást - és egyben lehetöséget Fehéroroszország és a Balti államok közelsége jelenti. A kihívás abban rejlik, hogy posztszovjet államokban a széles nyomtávú vasút a bevett, míg Lengyelországban az európai normálnyomtáv rendszeresített. Ez a helyzet ugyan jelentős beruházásokat igényel és erőteljesen determinálja az ország hídszerepét a kelet-nyugati irányú vasúti forgalomban. Ezt a helyzetet aknázná ki a kínai az „Egy övezet, egy út” (One belt, one road) terv is. Szintén a lengyel hídszerepet erősíti a Balti államok Lengyelországgal összemérhető ruszofóbiája is, amelynek keretében az Európai Hálózatfinanszírozási Eszköz (Connecting Europe Facility, CEF) finanszírozásával valósítják meg a Rail Baltica nevű, Lengyelországot és Észtországot összekötő kétvágányú, normálnyomtávú villamosított vasúti korridort (Rail Baltica).

A vasúti személyszállítás esetén egy új terv a V4-tagországokat összekötő gyorsvasút kiépítése. Bár a kapcsolat két nyomvonalon, kelet felé Debrecen és Kassa felé, vagy Debrecen és Nagyvárad felé is megvalósítható, a legnagyobb hasznosságot vélhetően az európai gyorsvasúti hálózatba integráltan a Bécsen keresztülhaladó nyomvonal hozhatja. A projekt előkészítését a 1174/2018. (III. 28.) kormányhatározat rendelte el, így a nyomvonal és a költségek meghatározása 2019 végére történhet meg.

\section{Energiabiztonság és klímaváltozás}

Lengyelország energiatermelését a fosszilis energiahordozók erőteljesen determinálják. A megújuló energiaforrások (elsősorban szél és biomassza) energiatermelési mixben betöltött szerepe 2008-tól jelentősen emelkedett, és 2016-ra a bruttó energiatermelés csaknem 14 százalékát tette ki (Raszkowski és Bartniczak, 2019; EB, 2018). A szilárd energiahordozók szerepe azonban a rendszerváltás óta lényegében nem csökkent (EB, 2018). (Lásd a 3. ábrát.) A fosszilis alapokon nyugvó energiatermelési összetétel következtében az ország szénlábnyoma kiemelkedő - az elektromosság szénintenzitása Lengyelországban megközelítőleg 700-750 g/kWh, míg Magyarországon 300-350 g/kWh (electricitymap.org). 


\section{Lengyelország bruttó energiatermelése energiahordozó szerint} 1990 és 2016 között

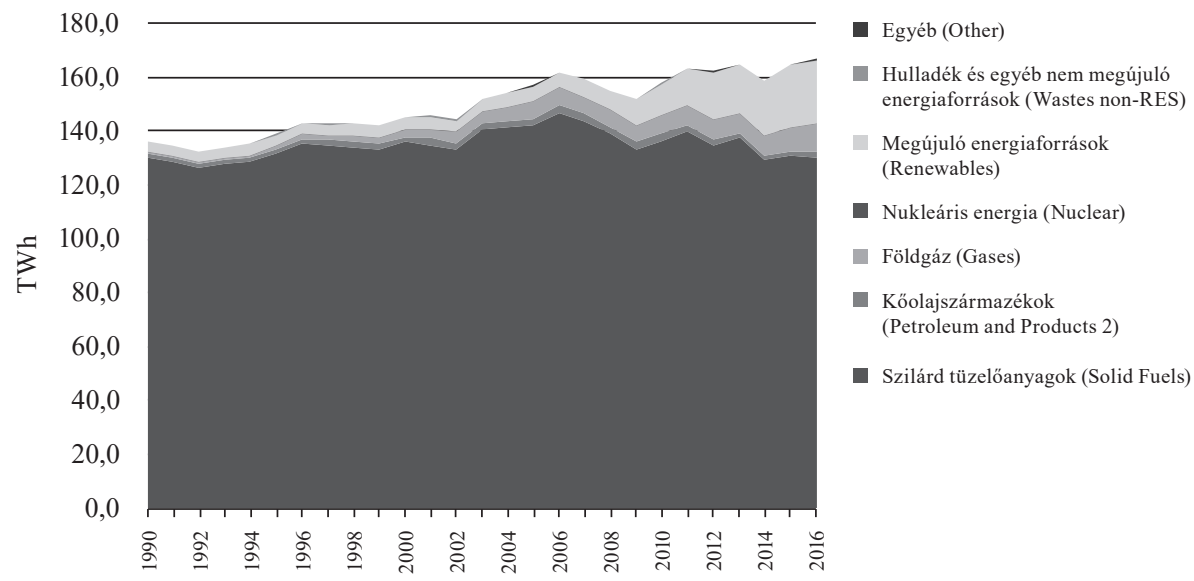

TWh, forrás: EB, 2018, saját szerkesztés.

Az energiatermelés alapját a dél-lengyelországi szénbányákban kitermelt fekete kőszén jelenti. A lengyel villamosenergia-termelés csaknem négyötödét a szénerőművekben állítják elő. A szénre épülő gazdaság által kibocsátott üvegházhatású gázok (ÜHG) jelentős mértékben járulnak hozzá a klímaváltozáshoz (Der Spiegel, 2018c), ezen felül az Európai Unióban Lengyelországban a leginkább szennyezett a levegö (Riedel, 2019).

A szén kiegészítésére, illetve helyettesítésére jelentősebb gázerőmü-kapacitás épült ki a rendszerváltást követően. A gáztüzelés az energiatermelés mellett - az alacsonyabb légszennyezés következtében - a háztartások fütésében is kedvező alternatívát nyújthat. Ugyanakkor Lengyelország földgáz tekintetében importra szorul - az ország 1944 óta importál földgázt Oroszországból, amelynek volumene 2018-ban 10 milliárd köbmétert tett ki. A lengyel kormány Oroszországgal szembeni aggodalmai következtében ez energiabiztonsági szempontból kockázatokat hordoz. Az import diverzifikálása érdekében 2018-ra elkészült Świnoujście-ben az LNG terminál, és 2018-ra a korábbi duplájára, 3 milliárd köbméterre növelte a Katarból származó import mennyiségét. Az LNG-kapacitás további növelését tervezik, amelynek keretében a kikötő 2020 utánra évente 7,5 milliárd köbméter gáz fogadására válik alkalmassá. A diverzifikáció másik eleme a balti-tengeri vezeték (Baltic Pipe), amelynek 
Konvergencia vagy közepes jövedelmi csapda? - Lengyelország lehetőségei...

megépülte után évi 8,78 milliárd köbméter norvég gáz szállítása oldható meg. A határos uniós tagországokhoz kapcsolódó vezetékszakaszok kiépítésével nem volna szükség a 2022-ben lejáró Gazprom-szerződés meghosszabbítására (Bloomberg, 2018).

Ugyanakkor a gazdaság dekarbonizációja jelentős erőfeszítéseket igényel míg az EU 2030-ra a megújuló energiaforrások 32 százalékos részarányának elérését tervezi, a lengyel kormány célszáma kevésbé ambiciózus, csupán 21 százalék (portfolio.hu, 2019). Ennek oka hármas:

1. a hazai szénen alapuló energiaipar kb. 100 ezer főt foglalkoztat, ami nemzetgazdasági szinten is jelentősnek tekinthető (portfolio.hu, 2019). Ezen felül a szénbányász szakszervezetek számos privilégiumot megőriztek, ami tovább erősíti érdekérvényesítő képességüket (Riedel, 2019);

2. az energiatermelés dekarbonizációja jelentős tőkebefektetéseket igényelne, ami a lakossági energiaárak emelését jelentené. Mivel ennek felvállalása politikailag érzékeny téma, a kormány a lakossági árak kiegyenlítésének „magyar megoldását” is számításba vette. Ugyanakkor a megoldás inflációra gyakorolt hatása, valamint az Európai Bizottság esetleges eljárása következtében ezt elvetették (Riedel, 2019);

3. Bár a légszennyezés tekintetében már a földgáz alapú fütésre való átállás is jelentős javulást okozhatna, az importfüggőség fokozásától való félelem, valamint a szén alacsony lakossági ára következtében egy ilyen folyamat valószínütlen.

Az ENSZ közgyülése által 2015-ben elfogadott „Fenntartható Fejlödési Keretrendszer 2030 - Agenda 2030" címü dokumentumban a 2015 és 2030 közötti időszakra vonatkozóan megfogalmazott célkitüzések megvalósítására Lengyelország 2017ben elfogadta a Felelős Fejlödési Stratégiát (Strategy for Responsible Development) (Raszkowski és Bartniczak, 2019). Az Agenda 2030 horizontális célrendszerében az energetikai fejlesztésekhez közvetlenül három cél tartozik (Megfizethető és tiszta energia [SDG 7], Fenntartható városok és közösségek [SDG 11], valamint a Fellépés az éghajlatváltozás ellen [SDG 13]), ugyanakkor az energiatermelés externális hatásai számos közvetett, járulékos célkitűzést érintenek. Riedel [2019] megjegyzése alapján ugyanakkor a lengyel kormány 1989 óta elfogadott energetikai stratégiái eddig rendre kudarcot vallottak.

Az energiatermelés szénintenzitása csökkentésének forrásigénye hatalmas, így a jelenlegi tervek alapján nem is várható 2030 -ig a szénfelhasználás csökkenése. 
A lengyel energiastratégia a 2030-2040 közötti időszakra a következő intézkedésekkel tervezi mérsékelni az energiatermelés szénintenzitását (portfolio.hu, 2019)

- a szárazföldi (onshore) szélerőmüvek leépítésével és tengeri (offshore) eröművek telepítésével. A szárazföldi kapacitások csökkentése nemcsak a már megvalósult beruházások leépítése, hanem az energiaellátás diverzifikálása szempontjából sem tekinthető hatékonynak;

- atomenergia-kapacitások kiépítésével. Krzysztof Tchórzewski energiaügyi miniszter 2019-es bejelentése alapján 2020-ban meghatározzák az első 1-1,5 GWe teljesítményű erőmű helyszínét, amelyet a tervek szerint 2033ban helyeznének üzembe. 2043-ig összesen 6-9 GWe nukleáris kapacitást adnának át ( $W N N, 2019)$. Komoly kockázatot jelent azonban, hogy az atomerőmü létesítése - a jelenlegi politikai irányzat mellett - kizárólag az orosz technológia kizárásával valósulhat meg, ami a verseny korlátozása következtében a beruházási költségek további növekedését okozza.

Az említetteken kívül a napenergia, valamint az LNG terminálokra építő rugalmasan szabályozható teljesítményủ gázerőművek az energiastratégia kiegészítő elemét jelenthetik.

\section{Összegzés}

Lengyelország Kelet-Közép-Európa meghatározó állama. Az ország nyugati orientációja megkérdőjelezhetetlen - 1999 óta a NATO, 2004 óta az Európai Unió tagállama, kül- és belpolitikáját erőteljesen befolyásolják az Oroszországgal kapcsolatos aggodalmak. Ezek indokolják, hogy

1. Lengyelország rendelkezik GDP-arányosan a NATO hatodik legmagasabb védelmi költségvetésével, több nagy volumenű fegyvervásárlási szerződést kötött az USA-val (lásd: Sikorsky helikopterek, Patriot rakéták, F-35 harci gépek), továbbá az ország jelezte szándékát egy állandó amerikai katonai bázis finanszírozására;

2. Földgázellátásának biztosítása érdekében a Balti-tenger partján az amerikai, illetve a katari LNG fogadására terminált létesített, amelynek bővítése a közeljövőben várható. Lengyelország elkötelezett a szomszédos országokhoz kapcsolódó vezetékek kiépítésében, létrehozva egy észak-déli energetikai tengelyt. 
Konvergencia vagy közepes jövedelmi csapda? - Lengyelország lehetőségei...

3. A közlekedési folyosó kiépítése során mind az észak-déli folyosók (lásd: Rail Baltica, Budapest-Varsó gyorsvasút), mind a Németország felé való kapcsolódás prioritást élvez.

Fontos kiemelni, hogy a jelenlegi kormány az Európai Unió magállamaival konfrontációs irányt képvisel, amire jó példa az Európai Unió kötelezettségszegési eljárását, valamint az EUMSZ 7. cikke szerinti eljárást kiváltó igazságügyi reform, vagy akár a lengyel euró bevezetésének szabotálása.

Véleményem szerint Lengyelország számára az EU magországaihoz való felzárkózáshoz több körülmény egyidejü teljesülése szükséges, amelyek a következők.

- Az EU poszt-brexit konstellációjában Lengyelország mind gazdaságilag, mind népességét tekintve jelentős politikai tényező lehet. A lengyel érdekeket erősebben figyelembe vevő mélyebb integráció következtében mind az EU, mind Lengyelország komolyabb geopolitikai tényező lehet, megteremtve így a Párizs-Berlin-Varsó-tengelyt - ami már a mai fö közlekedési folyosókhoz is illeszkedik.

- Lengyelország felvétele az eurózónába mind politikai, mind gazdasági téren előnyt jelenthetne mindkét fél számára.

- A brexit következtében Nagy-Britanniát elhagyó cégek számára az ingatlanárak, a szabad irodakapacitások, valamint az idegen nyelveket viszonylag jól beszélő városi populáció ideális telephelyet jelenthet a magas hozzáadott értékủ szektorok számára. Az esetlegesen hazatelepülő lengyel munkavállalók szintén hozzásegíthetik a gazdaság versenyképességének növelését, a nemzetközi szinten is sikeres kis- és középvállalkozási szektor kialakulását.

- A gazdasági szereplők számára a legfőbb lehetőséget az ország belső piaca jelenti, ami a külső szereplők számára belépési korlátot, a helyi gazdasági aktoroknak pedig a nemzetközi piacra lépéshez szükséges méret elérésének lehetőségét jelenti. A nemzeti bajnok cégek (például: LPP, Solaris Bus stb.) a magyar tapasztalatokhoz hasonlóan egy kritikus méret elérését követően gyakran szakmai befektetők felvásárlási célpontját jelentik.

- A több generációra tervező és nemzetközi szinten is versenyképes családi vállalkozások iparpolitikai támogatása jelentős potenciált hordozhat, ugyanis ezen vállalkozások a kritikus méret elérését követően is leginkább nyíltan múködő részvénytársasággá alakulnak, továbbá hosszú távú szemléletük a felek közötti nagyobb bizalmon alapuló vállalkozási kultúrát honosíthatnak meg. Problémát jelent, hogy ez a fejlődési út - jellegéből adódóan - stabil környezetet feltételez és meglehetősen időigényes. 
A felsorolt tényezők együttes teljesülésére a jelenlegi euszkeptikus kormányzat mellett csekély esély mutatkozik. Mindazonáltal fontos hangsúlyozni, hogy egy a mélyebb integrációból kimaradó, de az EU-val konszolidált viszonyt ápoló irány is jelentős kitörési potenciált rejthet. A jelenlegi ismeretek mellett ez tekinthető a leginkább valószínủ forgatókönyvnek.

\section{Felhasznált irodalmak}

\section{Folyóiratcikkek, könyvek}

A gazdasági válság... [2010]: A gazdasági válság és társadalmi következményei. Pénzügykutató alapítvány. Letölthető: https://penzugykutato.hu/sites/default/files/A\%20gazdasagi\%20 valsag\%20es\%20tarsadalmi\%20kovetkezmenyei-20100312_0.pdf

Bank Dénes [2017]: The double-dependent market economy and corporate social responsibility in Hungary. Corvines Journal of Sociology and Social Policy, Vol. 8., No. 1., 25-47. o.

Bohle, D. - Greskovits, B. [2012]: Capitalist Diversity on Europe's Periphery. Cornell University Press, Ithaca, New York.

Camagni, R. [1995]: The concept of innovative milieu and its relevance for public policies in European lagging regions. Papers in Regional Science, Vol. 74., Issue 4., 317-340. o.

Farkas Beáta [2017]: Piacgazdaságok az Európai Unióban. Akadémiai Kiadó, Budapest.

Goczek, E. - Partyka, K. J. [2019]: Too small to be independent? On the influence of ECB monetary policy on interest rates of the EEA countries. Economic Modeling, Vol. 78., május, 180-191. o. Letölthetö: https://doi.org/10.1016/j.econmod.2018.09.019

Hall, P. A. - Soskice, D. [2004]: An introduction to varieties of capitalism. In: Varieties of capitalism. The institutional foundations of comparative advantage. Oxford University Press, New York, 1-70. o.

Kolodko, G. W. [2017]: Economics and politics of the currency convergence: The case of Poland. Communist and Post-Communist Studies, Vol. 50., Issue 3., 183-194. o. Letölthetö: http://dx.doi. org/10.1016/j.postcomstud.2017.06.003

Kornai János [1999]: A rendszerparadigma. Közgazdasági Szemle, 46. évf., 7-8. sz., 585-599. o.

Kovács, K. - Scheppele, K. L. [2018]: The fragility of an independent judiciary: Lessons from Hungary and Poland and the European Union. Communist and Post-Communist Studies, Vol. 51., Issue 3. 189-200. o. Letölthetö: https://doi.org/10.1016/j.postcomstud.2018.07.005

Leven, B. [2011]: Avoiding crisis contagion: Poland's case. Communist and Post-Communist Studies, Vol. 44., Issue 3., 183-187. o. Letölthető: https://doi.org/10.1016/j.postcomstud.2011.07.001

Lisiakiewicz, R. [2018]: Poland's conception of European security and Russia. Communist and Post-Communist Studies, Vol. 51., Issue 2., 113-123. o. Letölthető: https://doi.org/10.1016/j. postcomstud.2018.04.001

Lux Gábor [2017]: A külföldi tőke által vezérelt iparfejlődési modell és határai Közép-Európában. Tér és Társadalom, 31. évf., 1. sz., 30-52. o. Letölthető: https://doi.org/10.17649/TET.31.1.2801

Nölke, A. - Vliegenthart, A. [2009]: Enlarging the varieties of capitalism. The emergence of dependent market economies in East Central Europe. World Politics, Vol. 61., Issue 4., 670-702. o.

Przychodzen, J. - Przychodzen, W. [2015]: Relationships between eco-innovation and financial performance - evidence from publicly traded companies in Poland and Hungary. Journal of Cleaner Production, Vol. 90., március 1., 253-263. o. Letölthető: http://dx.doi.org/10.1016/j. jclepro.2014.11.034 
Raszkowski, A. - Bartniczak, B. [2019]: On the Road to Sustainability: Implementation of the 2030 Agenda Sustainable Development Goals (SDG) in Poland. Sustainability, Vol. 11., Issue 2. Letölthetö: https://doi.org/10.3390/su11020366

Riedel, R. [2019]: Analyse: „Grüner Konservatismus“? Über die polnische Klima- und Energiepolitik. Bundeszentrale für politische Bildung. Letölthető: http://www.bpb.de/internationales/europa/ polen/285318/analyse-gruener-konservatismus-ueber-die-polnische-klima-und-energiepolitik letöltve: 2019. 08. 07.

Tarlea, S. - Freyberg-Inan, A. [2018]: The education skills trap in a dependent market economy. Communist and Post-Communist Studies, Vol. 51., Issue 1., 49-61. o.

\section{Újságcikkek, internetes források}

1174/2018. (III. 28.) Korm. határozat a Budapest-Varsó nagysebességủ vasútvonal részletes megvalósíthatósági tanulmányának elkészítéséröl.

Bloomberg [2018]. Letölthető: https://www.bloomberg.com/news/articles/2018-02-08/poland-bets-onlng-norwegian-gas-as-divorce-with-russia-looms. Letöltve: 2018. 12. 07.

Der Spiegel [2018a]: Präsident Duda wirbt für ständige US-Militärbasis in Polen. Letölthető: https:// www.spiegel.de/politik/ausland/besuch-bei-donald-trump-andrzej-duda-will-staendige-usmilitaerbasis-in-polen-a-1228810.html. Letöltve: 2019. 10. 06.

Der Spiegel [2018b]: Warschau mäßigt den Ton - und sonst nichts. Letölthető: http://www.spiegel. de/politik/ausland/eu-und-polen-warschau-maessigt-den-ton-und-sonst-nichts-a-1187067.html letöltve: 2018. 12. 14.

Der Spiegel [2018c]: Kohle ist unser größter Schatz. Letölthető: http://www.spiegel.de/wirtschaft/ unternehmen/klimakonferenz-polens-praesident-andrzej-duda-lobt-kohle-a-1241940.html letöltve: 2019. 08. 07.

Der Spiegel [2019a]: Europa? Gern, aber bitte ohne die Zumutungen. Letölthető: https://www.spiegel. de/politik/ausland/polen-konservative-siegen-bei-eu-wahl-wollen-aber-nur-die-guten-seiten-dereu-a-1269564.html. Letöltve: 2019. 08. 07.

Der Spiegel [2019b]: Um wen von der Leyen zittern muss. Letölthető: https:/www.spiegel.de/politik/ ausland/anwaerter-fuer-eu-kommission-anhoerungen-im-eu-parlament-beginnen-a-1289286. html. Letöltve: 2019. 10. 06.

FTSE Russell [é. n.]. Letölthető: https://www.ftserussell.com/about-us/our-story. Letöltve: 2019.11.21

G7 [2019]: A Pizza Huttól a Royal vodkán át a CCC-ig érezhetjük a lengyelek térfoglalását. Letölthető: https://g7.hu/vallalat/20190810/a-pizza-huttol-a-royal-vodkan-at-a-ccc-ig-erezhetjuk-alengyelek-terfoglalasat/. Letöltve: 2019. 10. 12.

Handelsblatt [2016]: „An der Nase herumgeführt” - Polen verärgert Airbus. Letölthető: https:// www.handelsblatt.com/unternehmen/handel-konsumgueter/streit-um-hubschrauber-vertragan-der-nase-herumgefuehrt-polen-veraergert-airbus/14670530.html?ticket=ST-22749612tb0kABoKQFzjFBIsQrVU-ap2 Letöltve: 2019. 10. 06.

Heinisch, R. [2019]: Politologe Heinisch: Populismus ist „dünne Ideologie”. Előadás a Salzburger Hochschulwoche rendezvényén. Letölthetö: http://www.salzburger-hochschulwochen.at/shw2019/ meldungen/politologe-heinisch-populismus-ist-duenne-ideologie Letöltve: 2019. 10. 06.

$H V G$ [2016]: Nagy Gábor: Solaris, a hódító lengyel buszgyártó. Stabil felépítmény. HVG, 38. évf., 5. sz., 58-59. o.

HVG [2018]: Nagy Gábor: Lengyel fast-fashion sikertörténet. Nagyravágyók. HVG, 40. évf., 26. sz., 56-57. o.

portfolio.hu [2019]: Elképesztő energiatervei vannak a lengyel kormánynak 2040-ig. Letölthetö: https://www.portfolio.hu/vallalatok/fenntarthatovilag/elkepeszto-energiatervei-vannak-alengyel-kormanynak-2040-ig.4.309639.html. Letöltve: 2019. 01. 07. 
PwC [2013]: Road building in Poland. The facts and the myths, experience and perspectives. Letölthetö: http://pzpb.com.pl/wp-content/uploads/2016/02/Road-building-in-Poland_ver_ang.pdf. Letöltve: 2019. 11. 22.

Reuters [2019]: U.S. backs proposed $\$ 6.5$ billion sale of 32 F-35 Lockheed jets to Poland. Letölthető: https://www.reuters.com/article/us-usa-poland-f-35/u-s-backs-proposed-6-5-billion-sale-of-32-f35-lockheed-jets-to-poland-idUSKCN1VW29R. Letöltve: 2019. 10. 06.

NATO [2019]: Defence Expenditure of NATO Countries (2012-2019). Communique PR/CP(2019)069 Letölthető: https://www.nato.int/nato_static_fl2014/assets/pdf/pdf_2019_06/20190625_PR2019069-EN.pdf Letöltve: 2019.11.21

$W N N$ [2019]: Poland already preparing for nuclear plant, says energy minister. Letölthető: http://worldnuclear-news.org/Articles/Poland-already-preparing-for-nuclear-plant,-says-e Letöltve: 2019. 08. 07.

\section{Adatforrások}

Cseh Nemzeti Bank. Letölthető: https://www.cnb.cz/en/monetary-policy/instruments/. Letöltve: 2019. 10. 12 .

EB [2018]. Letölthető: https://ec.europa.eu/energy/sites/ener/files/documents/countrydatasheets_ august2018.xlsx

Electricitymap.org. Letölthető: map https://www.electricitymap.org/. Letöltve: 2018. 12. 14.

Eurobarometer. Letölthető: https://ec.europa.eu/info/news/economy-finance/flash-eurobarometerpublic-support-for-introducing-the-euro-continues-to-rise_en. Letöltve: 2018. 12. 14.

Európai Központi Bank. Letölthető: https://www.ecb.europa.eu/stats/policy_and_exchange_rates/ key_ecb_interest_rates/html/index.en.html. Letöltve: 2019.10.12.

Eurostat [2017]. Letölthető: https://ec.europa.eu/eurostat/statistics-explained/index.php/Foreign language_skills_statistics. Letöltve: 2019.01.09.

Eurostat [2019]. Letölthetö: https://appsso.eurostat.ec.europa.eu/nui/submitViewTableAction.do

Lengyel Nemzeti Bank. Letölthetö: https://www.nbp.pl/homen.aspx?f=/en/dzienne/stopy_archiwum. htm. Letöltve: 2019. 10. 12.

Magyar Nemzeti Bank. Letölthetö: https://mnb.hu/Jegybanki_alapkamat_alakulasa?datefrom=2007.1 2.31.\&datetill $=2019.10 .12$.\&order $=0$. Letöltve: 2019.10 .12 .

UNCTAD [2019a]. Letölthető: https:/unctad.org/en/Pages/DIAE/World\%20Investment\%20Report/ Country-Fact-Sheets.aspx. Letöltve: 2019. 10. 06.

UNCTAD [2019b]. Letölthetö: https://unctad.org/Sections/dite_fdistat/docs/webdiaeia2014d3_POL. pdf. Letöltve: 2019. 10. 12.

Világbank. Letölthető: https://wits.worldbank.org/CountryProfile/en/Country/POL/Year/2016/ TradeFlow/EXPIMP/Partner/by-country\#. Letöltve: 2018. 12. 14. 